\title{
Determinants of Financial Performance of Maize Farms in Egba Division of Ogun State, Nigeria.
}

\author{
${ }^{1}$ A. O. Otunaiya, ${ }^{2}$ O. A. C Ologbon and ${ }^{3}$ O. Oyebanjo \\ ${ }^{I}$ Dept. of Agricultural Economics and Farm Management College of Agricultural Sciences, \\ Olabisi Onabanjo University, \\ ${ }^{2,3}$ Yewa Campus, P.M.B 012, Ayetoro, Ogun State, Nigeria.
}

\begin{abstract}
This study examines the financial performance of maize farms in Egba division of Ogun State, Nigeria, using primary data obtained, by use of simple random procedure, from 150 maize farm operators. A regression analysis was used to measure maize farmers' financial performance given farm and farmer's characteristics, production and marketing, and risk management strategies. Results indicate that income from off-farm sources, having production and marketing contracts, and having a written farm records lead to higher financial performance while participation in government price support programme lowered financial performance in maize farms.
\end{abstract}

Keywords: Financial Performance, Maize, Net Farm Income, Nigeria.

\section{Introduction}

Maize or Corn (Zea mays) is the third most important cereal grain after wheat and rice, providing nutrient for humans and animals and serving as a basic raw material for the production of starch, alcoholic beverages, and food sweeteners and recently as fuel [1]. Maize production has slightly increased over the past decade with area expansion being the main source of growth compared to negligible yield gains [2].

The need for good financial performance in maize production is to improve the scale of operations and productivity. With the rapid transformation of agriculture through employment of improved production methods such as the use of fertilizer, agrochemicals, improved seeds and credit facilities in order to meet the domestic and industrial demand for maize, examining the financial performance of maize farmers therefore, becomes a critical factor.

Maize farmers often lack the capital and the scale of operation to make profits and face high production costs (due to high cost of technologies and production systems)[3]. A maize farmer must rapidly acquire information about how to farm, how to manage a maize farm and how to adhere to Government regulations. Hence, this paper investigates the factors affecting profitability of maize farmers in the study area. A better understanding of the characteristics that influence returns and/or profits would be useful to maize farmers who wish to make changes in their farming operations in order to increase returns, and to policy makers who aim at formulating policies that help maize farmers maintain stable income.

\section{Methodology}

The study was conducted in Egba division of Ogun State. Six Local Government Areas constitute this geo-political division. Two of these Local Government Areas, namely, Odeda and Obafemi-Owode were purposively selected for their dominance in maize production in the Division. Data were collected by administering 200 sets of well structured questionnaires to maize farm operator. However, based on the adequateness of information received from respondents, data from 150 questionnaires were finally used for analysis. The primary data were collected directly from the field survey by the use of simple random procedure.

The survey collect data to measure the financial condition (farm income, expenses, assets, and debts) and operating characteristics of farm businesses, the cost of producing maize and the well-being of farmer households.

\subsection{Analytical procedure and model specification}

The appropriate measure of economic performance has been a topic of much interest among both economists and accountants. Some would argue that accrual net farm income (before taxes) is a good measure of overall financial performance while others suggest that return to labour and management is the preferable measure. Yet other researchers have used several financial ratios to measure farms' financial performance (e.g. [4];[5] and [6]. Kanffman and Tauer [7] used four different measures of farm performance for their study (labour management income per operator, labour management income per operator per cow, rate of return on equity capital, and rate of return on equity capital excluding appreciation). 
Financial performance is a subjective term and depends in part upon the time frame considered and goals of the farm business and/or farmer. Therefore, the criteria by which farm performance is measured must be clearly defined. Several studies have investigated the use of net farm income (NFI) as a performance measure ([8]; [9];[10]). The benefits of using NFI as a measure of profitability, have been well-documented in the past studies ([11],[12] and [6]. A positive value of NFI is critical to survival of the farm. Most farmers must balance equity growth with the need to meet short-term cash commitments. The use of NFI as a sole performance measure, however, may present a problem because it is an accounting measure and does not address opportunity costs. Hence, the use of NFI as an economic performance measure does not necessarily accurately reflect use of the resources base. In addition, the measure is a naira amount and as a result is difficult to compare across maize farm. In light of the above problem, following [6] modified net farm income (MNFI) per naira of assets was used as a measure of financial performance.

Ordinary least square regression models were used for the purpose of this study. In this model linear functional form was fitted to estimate the effect of farmer/farm characteristics on profitability of maize production. The choice of a lead equation among all fitted functional form was hinged on theoretical criterion, statistical significance of the R-square $\left(\mathrm{R}^{2}\right)$ and T-statistics [13].

\subsection{Conceptual Framework}

Consider a profit maximizing farm operator who in each period selects the combination of inputs and outputs that maximizes profits (total revenue minus total cost) subject to a production constraint. Specifically,

$\operatorname{Max} \Pi=\left[\sum \mathrm{P}_{\mathrm{i}} \mathrm{Q}_{\mathrm{i}}\left(\mathrm{k}, \mathrm{P}_{\mathrm{i}}, \gamma\right)\right]-\left[\sum \mathrm{C}_{\mathrm{j}}\left(\mathrm{Q}_{\mathrm{j}}, \mathrm{w}_{\mathrm{j}}, \theta\right)\right]$

Where $\Pi$ is net profits (net farm income), $\mathrm{P}_{\mathrm{i}}$ denotes a vector of output prices, and $Q_{i}$ denotes a vector of output produced. Production depends on the farm operator's level of human capital (education and experience), price of output, various farm characteristics, and managerial ability. On the cost side, $\mathrm{C}_{\mathrm{j}}$ represents

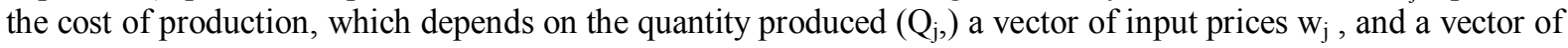
farm characteristics, and managerial ability, $\theta$. Based on equation 1 one can estimate the following model

$$
\mathrm{NFI}=\alpha_{\mathrm{o}}+\sum \alpha_{\mathrm{ij}} \mathrm{X}_{\mathrm{ij}}+\varepsilon
$$

Where: NFI is net farm income and $\mathrm{X}_{\mathrm{ij}}$ is a vector of farm, operator, and financial characteristics. However, because net farm income does not address opportunity costs as a measure of financial performance we replace the dependent variable (NFI) in equation 2 with modified net farm income (MNFI) per naira of assets. MNFI is defined as net farm income (NFI) plus interest expense, where NFI is gross farm income minus total farm operating expenses, excludes marketing expenses [12]. MNFI_DA is defined as the ratio of MNFI to total assets. MNFl_DA is hypothesized to be a function of operator and farm characteristics and management strategies used to manage the farm. Specifically, the following equation was estimated using an ordinary least squares procedure.

where,

$$
\text { MNFI_DA }=\alpha_{0}+\sum \alpha_{i j} X_{i j}+\varepsilon
$$

MNFl_DA is modified net farm income per naira of assets,

$\mathrm{X}_{\mathrm{ij}}, \quad$ are a set of farm operators', farm, and financial characteristics,

$\alpha_{\mathrm{ij}} \quad$ is a vector of parameters to be estimated, and,

$\varepsilon \quad$ is the unexplained random component.

$(\mathrm{i}=1 \ldots . . \mathrm{n})$

The independent variables hypothesized to affect the farm's financial performance encompass the three following areas: farm operator characteristics; farm characteristics such as production and marketing efficiency measures; and management strategies.

Table 1: Variables Definition and Measurement

\begin{tabular}{lll}
\hline \multicolumn{1}{c}{ Variable } & \multicolumn{1}{c}{ Description } & Measurement \\
\hline MNFI_DA & Modified net farm income per naira of asset & Naira \\
$\mathrm{X}_{1}$ & Age & Years \\
$\mathrm{X}_{2}$ & Level of formal education & Years \\
$\mathrm{X}_{3}$ & Off-farm income by household head & 1 if household head report off-farm income through \\
& & wages and salaries, O otherwise \\
$\mathrm{X}_{4}$ & Off-farm income by spouse & 1 if spouse reports off-farm income through wages \\
& & and salaries, 0 otherwise \\
$\mathrm{X}_{5}$ & Land (rented and leased) & Share of rented and leased hectare to total hectare \\
$\mathrm{X}_{6}$ & Farm ownership & 1 if farm fully owned, 0 otherwise. \\
$\mathrm{X}_{7}$ & Main occupation of the household head & 1 if the household head main occupation is farming, 0 \\
$\mathrm{X}_{8}$ & Value of maize sold & otherwise \\
$\mathrm{X}_{9}$ & Production contact & Naira \\
$\mathrm{X}_{10}$ & Marketing Contact & 1 if the farm had production contact, 0 otherwise \\
$\mathrm{X}_{11}$ & Ratio of value of machinery to value of production & 1 if the farm had marketing contact, 0 otherwise \\
\end{tabular}




\begin{tabular}{lll}
\hline $\mathrm{X}_{12}$ & Government price support programme & 1 if the farm received price support farm programme, \\
& Fotherwise \\
$\mathrm{X}_{13}$ & Farm Record & 1 if the farmer had a farm, 0 otherwise \\
$\mathrm{X}_{14}$ & Ratio of farm debt to farm assets & Naira \\
\hline
\end{tabular}

\subsection{Factors affecting financial performance of maize farmer}

\section{Results and Discussions}

The value of coefficient of determination $\left(\mathrm{R}^{2}\right)$ of 0.30 in Table 1 indicates that the explanatory variables used in MNFI_DA equation explained 30 percent of the variation in returns to farmers' labour and management. These levels of explained variation are fairly typical when the analyses are based on crosssectional data [14], [6]. The F-statistic, which tests the joint significance of the independent variables included in the model, is significant at the 1 per cent level of significance (Table 2).

The coefficient on off-farm income by the household head $\left(\mathrm{X}_{3}\right)$ is positive and statistically significant at the 10 percent level of significant. This result shows that working off the farm increases the returns to maize farming. Thus, suggest that a naira increase in off-farm income increase MNFI_DA by approximately 8 per cents. A possible explanation is that maize farmers who work off the farm have more money to acquire farm productive resources, resulting in higher output. This result is contrary to the finding of [6] who found a negative relationship between off-farm income and net farm income.

Table 1: Regression Analysis Result of the Modified Net Farm Income

\begin{tabular}{ll}
\hline Variables & MNFI_DA \\
\hline Intercept & -0.940 \\
& $-(0.426)$ \\
$\mathrm{X}_{1}$ & 0.937 \\
& $(0.682)$ \\
$\mathrm{X}_{2}$ & 0.480 \\
& $(0.036)$ \\
$\mathrm{X}_{3}$ & $0.805^{*}$ \\
& $(1.906)$ \\
$\mathrm{X}_{4}$ & 0.116 \\
& $(0.501)$ \\
$\mathrm{X}_{5}$ & 0.435 \\
& $(1.027)$ \\
$\mathrm{X}_{6}$ & -0.393 \\
& $-(0.905)$ \\
$\mathrm{X}_{7}$ & 0.117 \\
& $(0.247)$ \\
$\mathrm{X}_{8}$ & 0.202 \\
& $(0.150)$ \\
$\mathrm{X}_{9}$ & $0.143^{* *}$ \\
& $(2.343)$ \\
$\mathrm{X}_{10}$ & $0.253^{* * *}$ \\
$\mathrm{X}_{11}$ & $(6.122)$ \\
& 0.511 \\
$\mathrm{X}_{12}$ & $(0.080)$ \\
& $-0.133^{* *}$ \\
$\mathrm{X}_{13}$ & $-(2.454)$ \\
$\mathrm{X}_{14}$ & 0.642 \\
$\mathrm{R}^{2}$ & $(1.686)$ \\
Adjusted $\mathrm{R}^{2}$ & 0.109 \\
$\mathrm{~F}-\mathrm{test}$ & $(0.756)$ \\
\hline & 0.30 \\
& 0.27 \\
& $4.195^{* * *}$ \\
\hline
\end{tabular}

Note: $\quad * \quad$ t-value significant at 10 percent level, $\quad * *$ t-value significant at 5 percent level, $\quad * * * \quad t$-value significant at 1 percent level.

Having production contact with sources of improved inputs by maize farm, represented by variable $\mathrm{X}_{9}$, is another important variable that contributes to the success of maize farm. The results in table 2 indicate that production contact is positively correlated with the financial performance of maize farms. The result implies that increasing contact with sources of improved maize varieties and other farm inputs increases net farm income and MNFI per naira of assets (MNFI_DA). This result is consistent with the report of Kaufman and Tauer [7] . The coefficient on maize farm marketing contact $\left(\mathrm{X}_{10}\right)$ is positively signed and statistically significant at 1 percent level of significance. This suggests that financial performance, as measured by MNFI per naira of assets (MNFI_DA), increases with an increasing contact with maize buyers. 
Government price support programme are intended to decrease agricultural producers' risks [15. In this study, $\mathrm{X}_{12}$ represent government price support for maize farms. The coefficient of variable $\mathrm{X}_{12}$ is negative and statistically significant. This result is not consistent with the a-priori expectation and the findings in previous studies [16]; [11], [6]. The result suggests that increase in Government price support programme reduces maize farm net income and MNFI per naira of assets (MNFI_DA). A possible cause of the finding is that price support programmes in Nigeria are poorly implemented and lack adequate monitoring by concern government agencies, this problem coupled with the high level of corruption in public services would make a good-intended price support programme to negatively impact on maize farm holders.

The coefficient on farm record $\left(\mathrm{X}_{13}\right)$ is positive and statistically significant at the 10 percent level of significance. Results indicate that maize farm holders who have written farm records have higher financial performance (MNFI_DA) compared to maize farm holder with no written farm records. One possible explanation is that having a written farm records may help maize farmer obtain loans and grants from banks, Federal state and state government agricultural development agencies. Often, the authorities require that the farm holder have a farm - record showing farm inputs and outputs, income and expenditure as well as profits and losses.

\section{Conclusion and Recommendation}

The purpose of this study was to identify factors that contribute to the financial performance of maize farmers in Egba division of Ogun State. The results from this study indicate that off-farm income by maize farmers, having production and marketing contacts as well as keeping a good farm record would increase profit and financial performance of maize farm. Whereas, Government price support programme was identified to reduce maize farm profit hence lower their financial performance.

Based on the above findings the following recommendations were made:

i. Household head in maize farming should be encouraged to engage in off-farm income generating activities.

ii. Operations of Agro-service centers and Agricultural development project should be brought closer to maize farmers through extension agents in order to improve their production contact.

iii. Government should establish maize marketing board to regulate and stimulate marketing of maize.

iv. Government price support programmes for maize farm should be critically reviewed with the view to circumventing factors that makes price support counterproductive.

v. Extension agents should train farmers on the need for adequate farm records in maize production

\section{References}

[1] O. O. Alabi. Forecasting total maize, sorghum and Millet demanded by industries in Kaduna and Kano States of Nigeria: An application of Grafted Polynomials Model. In Umeh, Obinne and Lawal (eds). Prospects and Challenges of Adding value to Agricultural Products. Farm Management Association of Nigeria $22^{\text {nd }}$ Annual National Conference Proceeding. Makurdi, $8^{\text {th }}-11^{\text {th }}$ September, 2008, pp 35-44.

[2] FAO, Food and Agricultural Organization, Maize in human nutrition, Rome Italy, 1992

[3] A.O. Otunaiya, P.A. Okuneye and J.O.Y. Aihonsu, Pattern of Inorganic Fertilizer use

among Food Crop Farmers in Ogun State, Nigeria. Asian Journal of Agricultural Sciences 4(1): 2012, 26-31.

[4] G. O. Plumley, and R. H. Hornbaker, Financial Management Characteristics of Successful Farm Firms Agricultural Finance Review 51: 1991, 9-20.

[5] P. N. Ellinger,., P. J. Barry, T. L. Frey, and J. T. Scott. Financial Characteristics of Illinois Farm 1985-1986. University of Illinois at Urbana - Champaign, Department of Agricultural Economics, 1989

[6] A. K. Mishra, C. A. Wilson and R. P Williams, Technology Adoption, Management Practices, and Financial Performance of New and Beginning Farmers: Evidence from a National Survey. Unpublished paper presented at the 2007 AAEA annual meeting. Portland, July 29-Aug. 1:13-18, 2007.

[7] J. B. Kauffman and L.W. Tauer, Successful Dairy Farm Management Strategies Identified by Stochastic Dominance Analysis of Farm Records. Northeastern Journal of Agricultural and Resource Economics 15: 1986, 168-177.

[8] E. Melichar, Capital Gains versus Current Income in the Farming Sector. American Journal of Agricultural Economics 61: 1979, 1085-1102.

[9] K. L Haden, and L. A. Johnson, Factors which contribute to financial performance of selected Tennessee Dairies. Southern Journal of Agricultural Economics, 21: 1989, 105-112.

[10] S.O. Ewuola, Farm Credit as a Lever to Rural Development In S.F Adedoyin and J.O.Y Aihonsu (eds). Sustainable Development In Rural Nigeria. Proceedings of the Eighth Annual Conference of the Nigerian Rural Sociological Association. 1995, pp. 141-146.

[11] J. C. Fernandez-Cornejo, Hendricks, and A. Mishra, Technology Adoption and Off-farm Household Income: The case of Herbicide - Tolerant soybeans. Journal of Agricultural and Applied Economics 37(3): 2005, 549-563.

[12] A. K. Mishra, H. EL-Osta, and J. Johnson, Factors contributing to Earnings success of cash Grain Farms. Journal of Agricultural and Applied Economics 31(3): 1999, 31-48.

[13] A. L. Koutsoyiannis, Theory of Econometrics (Second Edition) Macmillian Press Ltd, London, 1977, pp 141-152

[14] H. S. EL-Osta, and J. D. Johnson. Determinants of Financial Performance of Commercial Dairy Farms. Technical Bulleting 1859 , Economic Research Service, U.S. Department of Agriculture, Washington D.C, 1998.

[15] B. K. Goodwin, and T.C. Schroeder, Human Capital, Producer Education Programs and the Adoption of Forward Pricing Methods, American Journal of Agricultural Economics, 76: 1994, 936-945.

[16] L. Calvin. Participation in the U.S. Federal Crop Insurance Program. U.S. Department of Agriculture, Economic Research Service, Washington DC Technical Bulletin No1800, 1992. 